\title{
USING PROBLEM-BASED LEARNING TO PROMOTE STUDENTS' USE OF HIGHER-ORDER THINKING SKILLS AND FACILITATE THEIR LEARNING
}

\author{
Nguyen Thi Minh Tam* \\ Faculty of Linguistics and Cultures of English-speaking Countries, \\ VNU University of Languages and International Studies, \\ Pham Van Dong, Cau Giay, Hanoi, Vietnam
}

Received 24 November 2017

Revised 20 March 2018; Accepted 30 March 2018

\begin{abstract}
This paper reports on an action research conducted in a university semantic course for senior students of English in Vietnam. With the assumption that problem-based learning (PBL) approach promotes students' thinking skills and facilitate students' learning, the researcher designed problem-based learning activities that required students' employment of higher-order thinking skills (HOTS) in their learning. By the time this paper was written, the action has finished its two cycles; each cycle lasted for nine weeks. The participants of the study were 31 students of Applied Linguistics in a college of foreign languages in Vietnam. The findings shed light on the extent to which PBL activities can promote students' use of HOTS and facilitate their learning in their English semantic class.
\end{abstract}

Keywords: higher-order thinking skills, problem-based learning (PBL), semantics

\section{Introduction}

Problem-based learning (PBL) is a learner-centered pedagogical approach that provides learners opportunities to engage in goal-directed inquiry. PBL is designed with the assumption that "when we solve the many problems we face every day, learning occurs" (Barrows \& Tamblyn, 1980, p.1). The implementation of PBL was pioneered in medical education in 1950s and then applied at McMaster University in Hamilton, Ontario, Canada in 1970s to teach students of medicine (Barrows \& Tamblyn, 1980). Since then, PBL has been applied in other fields; especially, PBL has been expanded to teacher education since 1980 (de Chambeau \& Ramlo, 2017; Hmelo-Silver, 2004; Hendry, Wiggins, \& Anderson, 2016; Schetino, 2016; Sipes, 2016). Recently, PBL has been applied

\footnotetext{
* Tel.: 84-989669422

Email: minhtambb@gmail.com
}

in teacher professional development or TESOL courses (Caswell, 2016; Hung \& Holen, 2011; Pourschafie \& Murray-Harvey, 2013; Zhang, Ludeberg, McConnell, Koehler, \& Eberhardt, 2010). In this study, problem-based approach was taken in designing learning activities for senior students of English in Vietnam in order to promote students' employment of higher-order thinking skills (HOTS) in their learning.

\section{Problem-based learning (PBL)}

Problem-based learning (PBL) usually starts with a problem raised to students, and the process of learning happens when students try to find solution to that problem. One key feature of PBL is that learning must be situated in authentic context (Barrows, 1994). PBL is "an instructional method that initiates students' learning by creating a need to solve an authentic problem" (Hung et al. 2008, p.486). In PBL, learners 
(usually in groups) analyze an open-ended problem which involves different aspects of conceptual knowledge and which can be solved in many different ways (Barrows, 2000; Hmelo-Silver, 2004) while teachers play the role of facilitators of the learning process rather than the disseminators of knowledge (Wilkerson \& Gijselaers, 1996), facilitating students in their process of thinking, reflecting, and collaborative inquiry. While solving problems, students figure out what to learn, how to learn, and finally, once they make their final decision on the best way to solve the problem, they learn both the domain knowledge and skills, and they practice using higher-order thinking skills in learning. According to Maggi (2003, p2) "in problem-based learning, the focus is on organizing curricular content around problem scenarios rather than the subjects or disciplines."

PBL is a promising approach to promote students conceptual knowledge during the learning process (HmeloSilver, Derry, Bitterman, \& Hatrak, 2009; Lambe, 2007; vanBerkel \& Schmidt, 2001; Walker \& Leary, 2009; Zhang et al, 2010). Scholkmann and Roters (2009) find out that PBL can have positive influence on students' self-assessment ability. Bell (2012, p.4) believes PBL helps students "to become independent learners and take responsibility for their learning". It is considered to be an innovative approach in teaching and learning because PBL's goals consist of conceptual and pedagogical content knowledge construction, collaboration, and self-directed, life-long learning (Hmelo-Silver \& Simone, 2013). However, PBL may be restrained by certain factors: "inadequate tutoring in PBL may influence the effectiveness of PBL as a strategy" (Barrows 1986, p.65). The use of PBL may also reduce teachers' control over content coverage, increase vulnerability and teaching-related workload (Bibeiro, 2011). Also, Hung, Mehl, and Holen (2013) have reported that some students found many problems in their PBL courses were too broad or vague for them to identify the goal or focus of the problem as well as the learning objectives.

\section{Higher-order thinking skills (HOTS) and students' learning}

There are different ways to define HOTS. Brookhart (2010) classifies the different definitions of HOTS into three major categories: HOTS as skills to transfer / apply what students have acquired or learnt into new contexts, HOTS as critical thinking skills, and HOTS as problem solving. In the sense of problem solving, "HOTS involve analyzing information to determine the problems, evaluating the problem and creating new workable solution" (Chinedu, Kamin, \& Olabiyi, 2015, p.36). HOTS are teachable and learnable, and the development of HOTS is not only for developing high cognitive capacities but also responsible for developing an all-round individual (Heong, Yunos, Hassan, Othman, \& Kiong, 2011). Taking the problem-based approach in teaching and learning, HOTS are the skills that enable learners to find a solution for a particular real life or professionspecific problems which cannot be solved by simply using a memorized solution but a combination of different skills such as logical analytical reasoning, reflective thinking and creative evaluating skills to develop a creative problem solving strategy. Problem solving, as noted by Bransford and Stein (1984), is the general mechanism behind all thinking and learning for understanding. Problem solving is essential for developing critical thinking, creative thinking and effective communication. 
Hung et al. (2008) state that to be an effective problem solver, students need to possess analytical, critical thinking, and metacognitive skills. Rajendran and Idris (2008) suggest that thinking skills support academic achievement while Brookhart (2010) asserts that holding students accountable for HOTS in learning enhances their motivation and learning results.

\section{The need for HOTS promotion to facilitate Vietnamese students' learning of linguistics}

In most Vietnamese tertiary institutions, HOTS has not become an integral part in the teaching and learning process yet. In our study conducted in 2015, my colleagues and I surveyed how students in the college under study used HOTS during their linguistic courses (Nguyen, Nguyen, Nguyen, and Doan, 2015) and it was revealed that teachers still "follow the familiar path of passing on the fragmented bits of information that students memorize, but still forget" (Newman 1990, p.41). This is understandable as in contemporary Vietnam's education system, the methods of teaching and learning are still very much teacher-centered. The primary teaching goal is to provide students with subject knowledge prescribed in the course books without adequate attention to developing the skills of utilizing what they have learnt in further study, future job, and in real life situations. After a survey on HOTS employment in linguistic courses in the college under study, Nguyen et al. (2015) report that linguistic teachers are often very successful in transferring the linguistic knowledge and skills to students, but they do not invest efforts on showing and encouraging students to be analytical and critical in their learning, or keenly discover how to apply the subject domain knowledge and skills in their current learning and in their future job. Also, teachers of these subjects do not require students to use HOTS much; instead, they require students to use thinking skills of lower levels, making the heavy course load even heavier to students. Most students, therefore, are passive acceptors (Forester \& Chau, 1999) and they were not accustomed to using HOTS such as evaluating, forming conclusion, decision making. In order to facilitate students' learning of these subjects, there seem to be a need to promote the use of HOTS in profession-specific learning. As students who take the linguistics courses were all senior student, their learning could be characterized with the adult learning characteristics coined by Knowles' (1984), including self-directedness, knowledge and life experiences, goal-orientedness, relevancy-orientedness, practicality, and collaboration. Accordingly, PBL is the appropriate teaching approach to promote students' HOTS employment, so that their learning is efficiently facilitated.

Basing on the contents of the linguistic courses, the expected learning outcomes of the learning program, and on Marzano and Kendall's (2007) four-level model of thinking skills, we, in Nguyen and Nguyen (2016) develop an evidencebased framework of how thinking skills of different levels could be used in the most popular English linguistic tasks in the college under study. 
Table 1. Thinking skills required in linguistic tasks at the college under study

\begin{tabular}{|c|c|c|c|c|}
\hline No & $\begin{array}{l}\text { THINKING SKILLS ACTUALLY } \\
\text { REQUIRED BY TEACHERS IN } \\
\text { LINGUISTIC TASKS (by March 2015) }\end{array}$ & $\begin{array}{l}\text { THINKING SKILLS THAT COULD } \\
\text { BE REQUIRED IN LINGUISTIC } \\
\text { TASKS (Nguyen and Nguyen 2016) }\end{array}$ & $\begin{array}{c}\text { EXAMPLES OF LINGUISTIC } \\
\text { TASKS }\end{array}$ & $\begin{array}{l}\text { MARZANO'S } \\
\text { TAXONOMY }\end{array}$ \\
\hline 4.4 & & $\begin{array}{l}\text { Adapt the existing } \\
\text { rules/framework to } \\
\text { investigate the linguistic } \\
\text { data }\end{array}$ & $\begin{array}{l}\text { Suggest the strategy to } \\
\text { translate English modal } \\
\text { devices into Vietnamese }\end{array}$ & \multirow{4}{*}{$\begin{array}{l}\text { UTILIZATION } \\
\text { LEVEL } 4\end{array}$} \\
\hline 4.3 & & $\begin{array}{l}\text { Experiment or test } \\
\text { the rules/processes in } \\
\text { students' own learning }\end{array}$ & $\begin{array}{l}\text { Speak the sentence in } \\
\text { Singaporean English } \\
\text { accent / using the Falling } \\
\text { Tune / the Dive. }\end{array}$ & \\
\hline 4.2 & & $\begin{array}{l}\text { Figure out a way to } \\
\text { solve the existing or } \\
\text { predicted problem }\end{array}$ & $\begin{array}{l}\text { How can the given } \\
\text { Facebook statuses be } \\
\text { devoid of sexism? }\end{array}$ & \\
\hline 4.1 & & $\begin{array}{c}\text { Decide the best among } \\
\text { the alternatives }\end{array}$ & $\begin{array}{l}\text { Which is the most } \\
\text { suitable pragmatic } \\
\text { strategy to be used in the } \\
\text { situation? }\end{array}$ & \\
\hline 3.4 & & $\begin{array}{l}\text { Specify (to defend or } \\
\text { judge) the arguments / } \\
\text { viewpoints on a certain } \\
\text { issues }\end{array}$ & $\begin{array}{l}\text { Explain how metaphors } \\
\text { work in the chosen text. }\end{array}$ & \multirow{4}{*}{$\begin{array}{l}\text { ANALYSIS } \\
\text { LEVEL } 3\end{array}$} \\
\hline 3.3 & & $\begin{array}{c}\text { Form conclusions } \\
\text { from the findings about } \\
\text { linguistic data }\end{array}$ & $\begin{array}{c}\text { What type of genre is } \\
\text { being used in the text } \\
\text { chosen? }\end{array}$ & \\
\hline 3.2 & & $\begin{array}{c}\text { Generalize in terms } \\
\text { of broader linguistic } \\
\text { categories / principles / } \\
\text { visuals }\end{array}$ & $\begin{array}{l}\text { What are the } \\
\text { communicative strategies } \\
\text { that speaker A uses in the } \\
\text { conversation? }\end{array}$ & \\
\hline 3.1 & $\begin{array}{l}\text { Classify, compare and } \\
\text { contrast the issues / } \\
\text { different views on the } \\
\text { issues }\end{array}$ & $\begin{array}{l}\text { Classify, compare and } \\
\text { contrast the issues / } \\
\text { different views on the } \\
\text { issues }\end{array}$ & $\begin{array}{l}\text { Classify the cohesive } \\
\text { devices used in the texts. }\end{array}$ & \\
\hline 2.4 & $\begin{array}{c}\text { Represent the language } \\
\text { chunks using the given } \\
\text { models }\end{array}$ & $\begin{array}{c}\text { Represent the language } \\
\text { chunks using the given } \\
\text { models }\end{array}$ & $\begin{array}{l}\text { Analyze the constituents } \\
\text { of the clause: } \\
\text { He asked me to open the } \\
\text { door for him. }\end{array}$ & \multirow{4}{*}{$\begin{array}{l}\text { COMPREHEN- } \\
\text { SION } \\
\text { LEVEL } 2\end{array}$} \\
\hline 2.3 & $\begin{array}{l}\text { Illustrate the linguistic } \\
\text { concepts(s) / phenomena }\end{array}$ & $\begin{array}{l}\text { Illustrate the linguistic } \\
\text { concepts(s) / phenomena }\end{array}$ & $\begin{array}{l}\text { Make } 2 \text { clauses in SOV } \\
\text { pattern and } 2 \text { clauses in } \\
\text { SVOC pattern. }\end{array}$ & \\
\hline 2.2 & $\begin{array}{c}\text { Describe the relationship } \\
\text { between the language } \\
\text { chunks }\end{array}$ & $\begin{array}{l}\text { Describe the } \\
\text { relationship between the } \\
\text { language chunks }\end{array}$ & $\begin{array}{l}\text { Describe the structure of } \\
\text { this noun phrase. } \\
\text { The beautiful lady in pink } \\
\text { over there. }\end{array}$ & \\
\hline 2.1 & $\begin{array}{c}\text { Describe the key part of } \\
\text { the language chunks }\end{array}$ & $\begin{array}{c}\text { Describe the key part of } \\
\text { the language chunks }\end{array}$ & $\begin{array}{l}\text { Transcribe the following } \\
\text { words in IPA. } \\
\text { watch, statue, strategic }\end{array}$ & \\
\hline
\end{tabular}




\begin{tabular}{|c|c|c|c|c|}
\hline 1.4 & $\begin{array}{l}\text { Identify the different } \\
\text { types of certain linguistic } \\
\text { notions or phenomenon }\end{array}$ & $\begin{array}{l}\text { Identify the different } \\
\text { types of certain } \\
\text { linguistic notions or } \\
\text { phenomenon }\end{array}$ & $\begin{array}{c}\text { State the morphological } \\
\text { processes in the word: } \\
\text { interpersonal }\end{array}$ & \multirow{4}{*}{$\begin{array}{l}\text { RETRIEVAL } \\
\text { LEVEL } 1\end{array}$} \\
\hline 1.3 & $\begin{array}{c}\text { Determine if the } \\
\text { statements are true or } \\
\text { false }\end{array}$ & $\begin{array}{c}\text { Determine if the } \\
\text { statements are true or } \\
\text { false }\end{array}$ & $\begin{array}{c}\text { Decide whether the } \\
\text { statement is T or F: } \\
/ \mathrm{m} / \text { and } / \mathrm{b} / \text { are bilabial } \\
\text { sounds. }\end{array}$ & \\
\hline 1.2 & $\begin{array}{c}\text { List the types or name the } \\
\text { concept(s)/ issue(s) being } \\
\text { described }\end{array}$ & $\begin{array}{l}\text { List the types or name } \\
\text { the concept(s)/ issue(s) } \\
\text { being described }\end{array}$ & $\begin{array}{l}\text { What are the } 3 \\
\text { characteristics of } \\
\text { antonyms? }\end{array}$ & \\
\hline 1.1 & $\begin{array}{l}\text { Recognize a concept } \\
\text { from a list of descriptions }\end{array}$ & $\begin{array}{l}\text { Recognize a concept } \\
\text { from a list of } \\
\text { descriptions }\end{array}$ & $\begin{array}{l}\text { Circle the definition of } \\
\text { conceptual meaning: } \\
\text { What the word refers to. } \\
\text { The dictionary definition } \\
\text { of the word. } \\
\text { The grammatical } \\
\text { category of the word. } \\
\text { The speaker's evaluation } \\
\text { on using the word. }\end{array}$ & \\
\hline
\end{tabular}

Table 1 is the comparison between Nguyen and Nguyen's (2016) framework and the thinking skills that students were currently required to use in linguistic tasks at the time of Nguyen et al.'s (2015) survey. Table 1 shows that most Marzano's level 3 and 4 thinking skills were not required in the linguistic tasks. This action research, thus, aimed to foster these missing thinking skills for students, and accordingly, facilitate their English semantics learning. Marzano's level 3 and 4 thinking skills, as presented in Table 1, as well as other skills in the same levels, were integrated with the domain knowledge and skills of semantics in the problem-based tasks, i.e. the problem cases in the course were designed so that students had to employ thinking skills during the process of problem solving.

\section{The study}

\subsection{Overview of the study}

The research question of this study is: To what extent could the problem-based learning activities promote students' use of HOTS in learning, and facilitate their learning? The study was conducted in the design of an action research. PBL approach was applied in teaching English Semantics to $4^{\text {th }}$ year students of Applied Linguistics (English major). By the time this paper was written, the action has completed its second cycle.

\subsection{Instrumentation}

The study was conducted in two stages: preliminary investigation and the action.

\subsubsection{Preliminary investigation}

In early summer 2015, in the role of Student Advisor, I had the chance to receive students' inquiries related to how they were going to use what they learnt in linguistic subjects in their future jobs. I then figured out that most of the students of English in my college, and also other Vietnamese students, ingenuously believe that the job of language teachers, writers, or translators could be fulfilled with good language proficiency and almost no learning of linguistics. Such a fallacy resulted from the fact that, for several decades now, the need for English in Vietnam has been so high that many of these students had already started their jobs as tutors or English teaching assistants, or tour guides, or translators before they learnt any 
linguistic courses at university. Linguistic subjects were something pure theoretical and far from essential and practical to them; so their motivation to learn these subjects was often low. In my informal discussion with students of research. By the time this paper was written, the study has gone through the preliminary investigation and two cycles (in Fall 2015 and Fall 2016), as summarized in Figure 1.

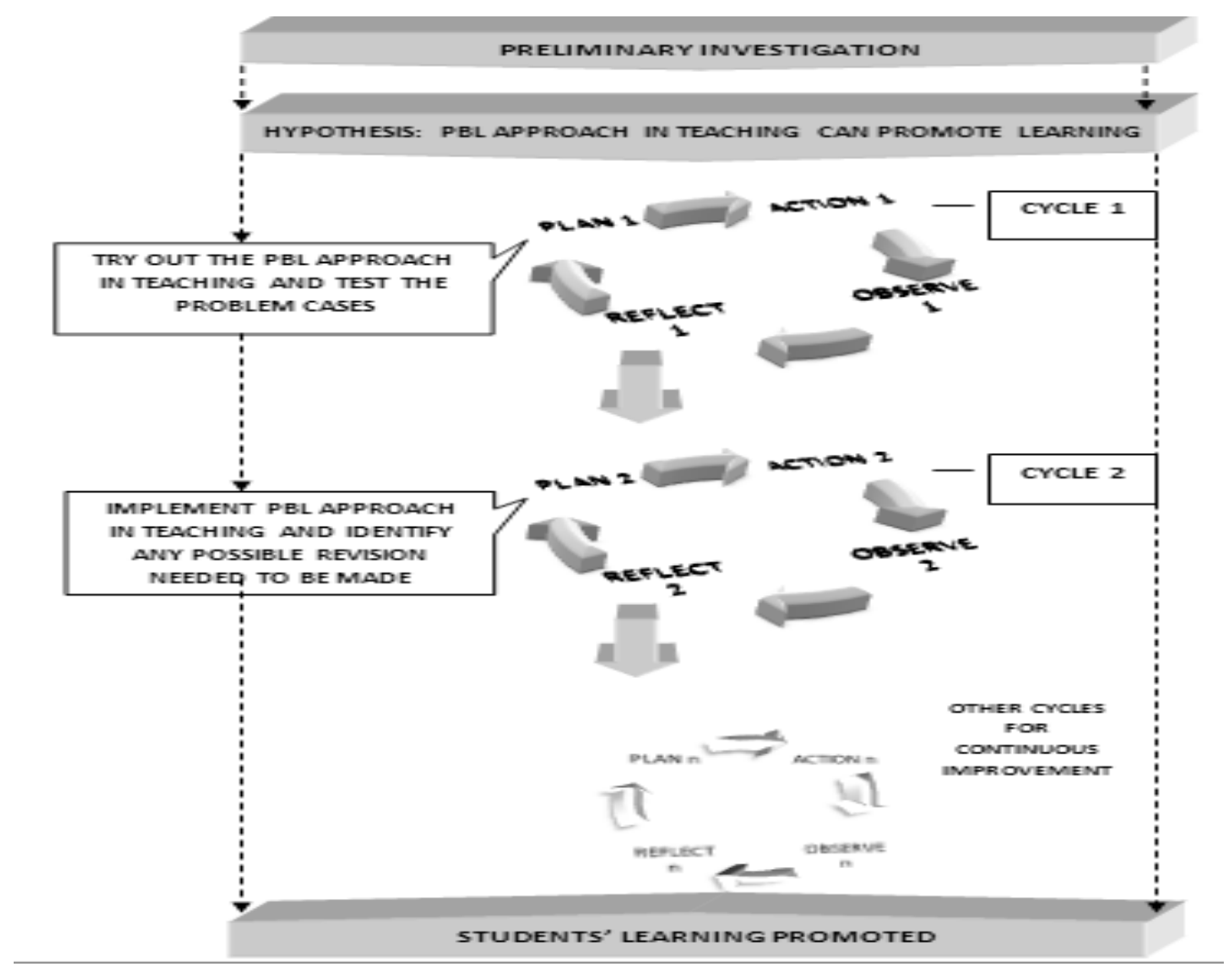

Figure 1 . The action cycles in the study

Applied Linguistics in the orientation week of the English Semantics Fall 2015 course - some students still expressed their concern about "is it necessary to learn these linguistic subjects?" and about "is there any application of the concepts and analyzing skills of phonology, morphology, syntax, and even semantics in our jobs and life?" I therefore came to the hypothesis that PBL is an appropriate approach to encourage students' use of HOTS in meaningful learning activities, thus facilitate their learning.

\subsubsection{The action}

The action in this study was designed in Burns' (2010) cyclical model of action
The action started at week 2 and ended at week 10, and PBL was applied in a partial approach (Ribeiro, 2011), that is, problembased approach was used in only one subject of semantics (not the whole curriculum), and at only given points of the course. The problem cases were designed using Hung's (2009) 3C3R model (Figure 2), taking into consideration the content knowledge, contextualizing domain knowledge, and the connection within each problem case, among the problem cases or between the problems and other contextual features. Each problem was designed as a chance for students to research, reason, and reflect on what they have learnt or experienced. 


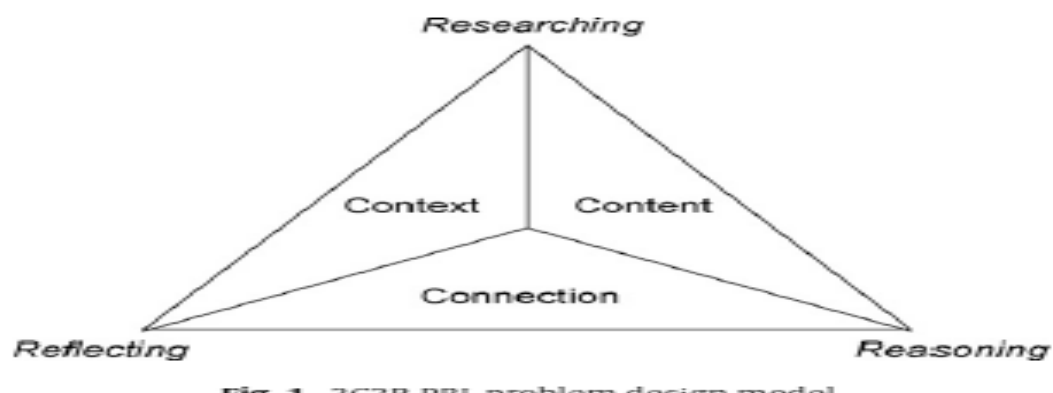

Fig. 1. 3C3R PBL problem design model,

Figure 2. The 3C3R PBL problem design model (Hung 2009)

In each cycle, four problem cases, in the format of rule induction, which was categorized to be increasing in the degree classified to be rather well-structured. The of ill-structuredness according to Jonassen's last problem case was designed as strategic (2000) classification (Figure 3), were performance, which was classified towards used: the first problem case was designed the ill-structured end.
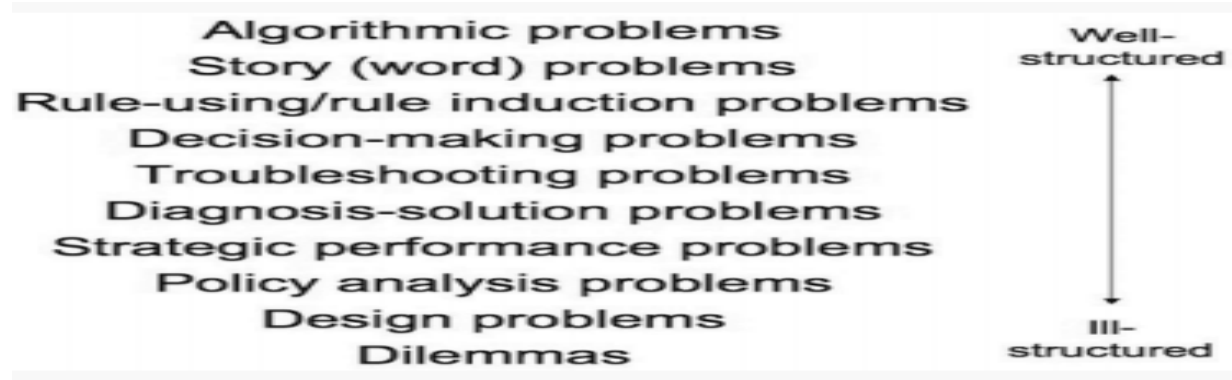

Figure 3. Typology of problem types (Jonassen 2000)
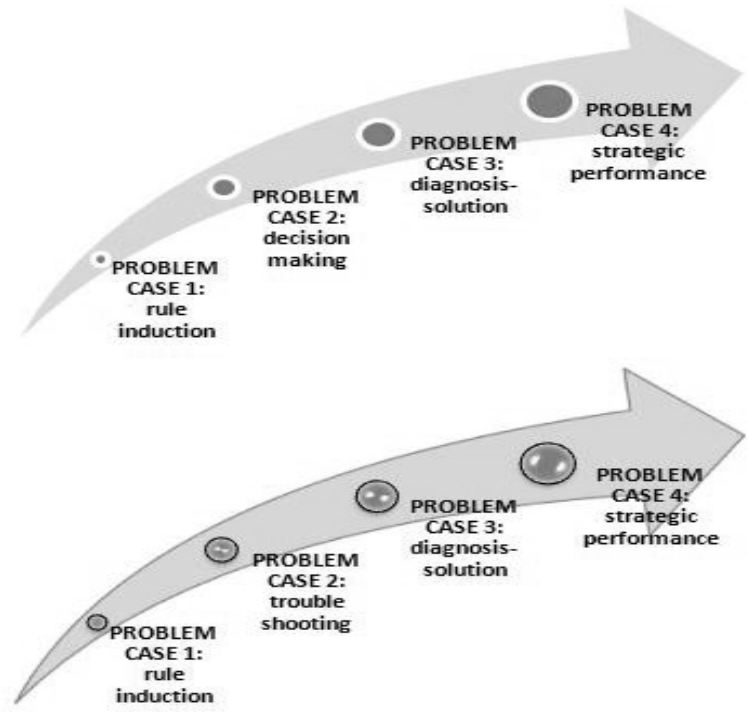

Cycle 1

Figure 4. The problem cases in two cycles 
As can be seen in Figure 4, and also Figure 5 below, the problem cases increased in terms of HOTS required to solve the problem, students' experience in problem solving, and students' reasoning skills (Jonassen \& Hung 2008, p.8), i.e. the first problem case was designed so that students were required to used HOTS of level 3 in Marzano and Kendall's (2007) model of thinking skills (such as comparing and contrasting, editing, revising, evaluating, error analyzing, forming conclusion, specifying, judging), while in the other three problems cases, students were required to use HOTS of both level 3 and level 4 (low) in Marzano and Kendall's (2007) model of thinking skills (such as decision making, problem solving, developing a strategy for a certain job). The reason why I decided to start at level 3 and stop at level 4 (low) was the expected learning outcome of the course and of the program curriculum. In order to fulfill these problem-based tasks, students had to participate in goal-directed learning, participating in processes of brainstorming, group discussion, and decision making.

\subsubsection{Participants}

The participants of both cycles were senior students of applied linguistics (English major): 16 students in cycle 1 (coded as S1.01 to S1.16) and 15 students of cycle 2 (S2.01 to S2.15). It was expected that after graduation, they would become teachers of English, editors, translators or interpreters; those who pursue extra certificates in journalism will become journalist who write their articles in English. By the time problem-based learning was introduced to them in their English semantics course, students had learnt quite many subjects which cover different linguistic areas: phonetics and English phonology, morphology, syntax, and a brief introduction to pragmatics, discourse analysis; so they had fairly good general understanding in linguistics. Each week, they had a three-hour English Semantics session. It was expected that after finishing the course, students would grasp the fundamentals including the concepts, relations, and main issues, both traditional and modern, of semantics and would be able to conduct small research in semantics.
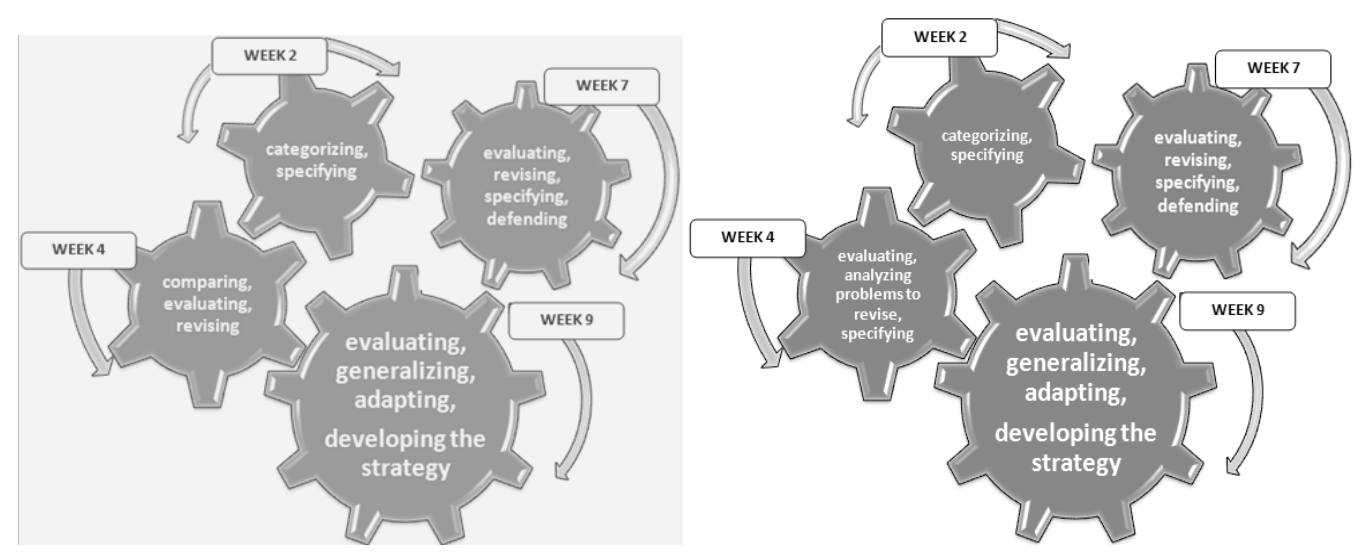

Figure 5. The requirements of HOTS throughout the PBL learning activities

In addition, the problem cases also increased in the breadth of domain knowledge and skills required. The brief description of the problem cases, requirement of HOTS, and the tasking procedures in two cycles is summarized in Table 2.

\subsection{Findings and discussion.}

As the study has finished its two cycles, the findings are discussed in two different cycles. The description of the intervention in the two cycles could be summarized in Table 2 below: 
Table 2. The description of the problem-based cases used in English Semantic course

\begin{tabular}{|c|c|c|c|c|c|}
\hline \multirow[b]{2}{*}{ Week } & \multirow{2}{*}{$\begin{array}{c}\text { Domain } \\
\text { knowledge and } \\
\text { skills required }\end{array}$} & \multicolumn{2}{|r|}{ Second cycle } & \multirow[b]{2}{*}{$\begin{array}{l}\text { The problem } \\
\text { case }\end{array}$} & \multirow[b]{2}{*}{$\begin{array}{l}\text { Teacher's instruction } \\
\text { on the tasking }\end{array}$} \\
\hline & & $\begin{array}{l}\text { The problem } \\
\text { case }\end{array}$ & $\begin{array}{c}\text { Teacher's instruction } \\
\text { on the tasking }\end{array}$ & & \\
\hline 2 & $\begin{array}{c}\text { General } \\
\text { understanding } \\
\text { of phonology, } \\
\text { syntax, } \\
\text { pragmatic, } \\
\text { discourse } \\
\text { analysis }\end{array}$ & $\begin{array}{l}\text { 1. How to use } \\
\text { the linguistic } \\
\text { knowledge and } \\
\text { skills you've } \\
\text { learnt in your } \\
\text { future job? }\end{array}$ & $\begin{array}{l}\text { Task: write in } 200- \\
300 \text { words; say how } \\
\text { linguistic knowledge } \\
\text { and language analysis } \\
\text { skills would help you } \\
\text { do your future jobs. } \\
\text { (individual, in class) }\end{array}$ & $\begin{array}{l}\text { 1. How to use } \\
\text { the linguistic } \\
\text { knowledge } \\
\text { and skills } \\
\text { you've learnt } \\
\text { in your future } \\
\text { job? }\end{array}$ & $\begin{array}{c}\text { Task 1: Discuss } \\
\text { in pair to recall } \\
\text { the contents of the } \\
\text { previous linguistic } \\
\text { courses. } \\
\text { Task 2: Write in } 200 \\
\text { - } 300 \text { words, say how } \\
\text { linguistic knowledge } \\
\text { and language analysis } \\
\text { skills would help you } \\
\text { do your future jobs. } \\
\text { (in class, after } \\
\text { orientation session). }\end{array}$ \\
\hline 4 & $\begin{array}{c}\text { Knowledge } \\
\text { about } \\
\text { synonymy, } \\
\text { antonymy, } \\
\text { syntactic and } \\
\text { rhetoric rules, } \\
\text { componential } \\
\text { analysis and } \\
\text { sense relation } \\
\text { analysis skills }\end{array}$ & $\begin{array}{l}\text { 2. How to use } \\
\text { the linguistic } \\
\text { knowledge } \\
\text { and skills } \\
\text { you've learnt } \\
\text { in the issues } \\
\text { of synonymy, } \\
\text { antonymy in } \\
\text { improving job } \\
\text { application } \\
\text { letters }\end{array}$ & $\begin{array}{l}\text { Task 1: discuss in pair, } \\
\text { give comments on the } \\
\text { wording of the letters } \\
\text { and make prediction } \\
\text { about whether the } \\
\text { writer will be called } \\
\text { for an interview or } \\
\text { not. (pair, in class) } \\
\text { Task 2: substitute } \\
\text { some words in one of } \\
\text { the two application } \\
\text { letters with their } \\
\text { synonyms or } \\
\text { antonyms, then state } \\
\text { how the changes affect } \\
\text { the styles and the } \\
\text { possibility of being } \\
\text { called for an interview } \\
\text { (individual, at home) }\end{array}$ & $\begin{array}{l}\text { 2. The given } \\
\text { application } \\
\text { letters were } \\
\text { not yet good } \\
\text { enough for } \\
\text { the applicants } \\
\text { to be } \\
\text { interviewed. } \\
\text { What changes } \\
\text { are to be made } \\
\text { and why? }\end{array}$ & $\begin{array}{l}\text { Students discussed } \\
\text { in pair to identify } \\
\text { the problems and } \\
\text { revise them, the } \\
\text { teacher facilitated } \\
\text { if students needed } \\
\text { more clarification } \\
\text { during the discussion } \\
\text { and give guiding } \\
\text { questions during the } \\
\text { presentation. } \\
\text { (before the lecture } \\
\text { on Sense relations, } \\
\text { discuss in pair then } \\
\text { present in class) }\end{array}$ \\
\hline 7 & $\begin{array}{c}\text { Knowledge } \\
\text { about } \\
\text { synonymy, } \\
\text { antonymy, } \\
\text { hyponymy, } \\
\text { meaning } \\
\text { transference, } \\
\text { meaning } \\
\text { transference } \\
\text { classifying, and } \\
\text { sense relation } \\
\text { analysis skills }\end{array}$ & $\begin{array}{l}\text { 3. As a writer / } \\
\text { teacher/ editor, } \\
\text { how to use } \\
\text { the linguistic } \\
\text { knowledge and } \\
\text { skills you've } \\
\text { learnt about } \\
\text { synonymy, } \\
\text { antonymy, } \\
\text { hyponymy, } \\
\text { or meaning } \\
\text { transference } \\
\text { in improving } \\
\text { your own/ } \\
\text { your students' } \\
\text { / other writers' } \\
\text { writing. }\end{array}$ & $\begin{array}{l}\text { Task 1: make changes } \\
\text { to the text (your } \\
\text { friend's writing) } \\
\text { by substituting the } \\
\text { words with their } \\
\text { synonyms, antonyms, } \\
\text { or hyponyms, or add } \\
\text { different types of } \\
\text { meaning transference } \\
\text { to the text. (in group } \\
\text { of students' choices, at } \\
\text { home) } \\
\text { Task 2: present the } \\
\text { changes they made } \\
\text { to the text with } \\
\text { explanation (compare } \\
\text { and contrast the } \\
\text { original version and } \\
\text { the revised version, } \\
\text { give well-supported } \\
\text { arguments for the } \\
\text { changes) (week 8) }\end{array}$ & $\begin{array}{l}\text { 3. The given } \\
\text { writings are } \\
\text { not yet good } \\
\text { enough to be } \\
\text { used as sample } \\
\text { writings for } \\
\text { students or } \\
\text { other writers. } \\
\text { Make changes } \\
\text { in terms of } \\
\text { lexical choices } \\
\text { and figure } \\
\text { of speech to } \\
\text { make them the } \\
\text { ideal sample } \\
\text { writing. }\end{array}$ & $\begin{array}{l}\text { Students discuss in } \\
\text { group to choose the } \\
\text { most appropriate } \\
\text { procedure to deal } \\
\text { with the problem } \\
\text { case, the teacher } \\
\text { facilitated via email } \\
\text { when students needed } \\
\text { clarification or further } \\
\text { consultation on the } \\
\text { process. } \\
\text { (after the lecture } \\
\text { on Meaning } \\
\text { Transference, work } \\
\text { in group (teacher } \\
\text { assigned students into } \\
4 \text { groups), prepare at } \\
\text { home and present in } \\
\text { class) }\end{array}$ \\
\hline
\end{tabular}




\begin{tabular}{|c|c|c|c|c|c|}
\hline 9 & $\begin{array}{l}\text { Knowledge } \\
\text { about modality, } \\
\text { syntactic } \\
\text { analysis skills, } \\
\text { modality } \\
\text { analyzing and } \\
\text { categorizing } \\
\text { skills, and } \\
\text { translation } \\
\text { skills }\end{array}$ & $\begin{array}{l}\text { 4. As a } \\
\text { translator / } \\
\text { teacher, how } \\
\text { to use the } \\
\text { linguistic } \\
\text { knowledge } \\
\text { and skills } \\
\text { you've learnt } \\
\text { in the issues of } \\
\text { modality when } \\
\text { translating } \\
\text { a text from } \\
\text { English into } \\
\text { Vietnamese } \\
\text { (and vice } \\
\text { versa) and } \\
\text { evaluate the } \\
\text { quality of your } \\
\text { own / others' } \\
\text { translated } \\
\text { texts. }\end{array}$ & $\begin{array}{l}\text { Task 1: translate a } \\
\text { text in English into } \\
\text { Vietnamese, focusing } \\
\text { on the equivalence } \\
\text { of modality } \\
\text { manifestation devices } \\
\text { (in group assigned by } \\
\text { teacher, at home) } \\
\text { Task } 2 \text { : give } \\
\text { comments on the } \\
\text { equivalence in } \\
\text { modality between } \\
\text { the original text } \\
\text { and your friend's } \\
\text { translated version; } \\
\text { give suggestions } \\
\text { to improve the } \\
\text { translation quality. } \\
\text { (in group assigned by } \\
\text { teacher, at home) } \\
\text { Task } 3 \text { : present the } \\
\text { changes made to } \\
\text { the translation with } \\
\text { explanation (compare } \\
\text { the original and the } \\
\text { revised versions, } \\
\text { give well-supported } \\
\text { arguments for the } \\
\text { changes) (week 10) }\end{array}$ & $\begin{array}{l}\text { 4. The } \\
\text { translated } \\
\text { versions } \\
\text { are not yet } \\
\text { the most } \\
\text { equivalent } \\
\text { enough to } \\
\text { the original } \\
\text { version in } \\
\text { English, } \\
\text { especially } \\
\text { in terms of } \\
\text { modality. } \\
\text { Make } \\
\text { changes to the } \\
\text { translation. } \\
\text { How is } \\
\text { modality in } \\
\text { English and } \\
\text { Vietnamese } \\
\text { the same and } \\
\text { different? } \\
\text { Suggest the } \\
\text { best strategy } \\
\text { to translate } \\
\text { modality } \\
\text { manifestation } \\
\text { devices. }\end{array}$ & $\begin{array}{l}\text { Students discuss in } \\
\text { group to choose the } \\
\text { most appropriate } \\
\text { procedure to deal } \\
\text { with the problem } \\
\text { case, the teacher } \\
\text { facilitated via email } \\
\text { when students needed } \\
\text { clarification or further } \\
\text { consultation on the } \\
\text { process. } \\
\text { (after the lecture } \\
\text { on Modality, work } \\
\text { in group (teacher } \\
\text { assigned students into } \\
4 \text { groups), prepare at } \\
\text { home and present in } \\
\text { class) }\end{array}$ \\
\hline
\end{tabular}

\subsubsection{Cycle 1}

Cycle 1 was conducted in Fall semester of 2015 - 2016 academic year.

Action and Observation. As seen in Table 2, the 4 problem cases in cycle 1, all designed as lecture-based (Barrows 1986), were all accompanied by the teacher's detailed instructions on the steps to take -2 or 3 tasks in each case - and how to fulfill the tasks. Such instructions, together with other guiding efforts, were made with the aim to offer students the most coaching possible in their very first attempts in using HOTS in their learning. The assumption behind the construction of those tasks was that: students' success in fulfilling the tasks was the evidence of their HOTS employment. While students were working (brainstorming, discussing, writing, presenting) with the problem cases in during the lesson, I observed how they struggled to solve problems, and how they contributed to the pair or group discussion. Students' motivation in problem solving, their comments about the problem difficulty or consultation about tasking were also observed in the lesson and through informal discussion with students (in person or via email). After the intervention, I also conducted a semistructured focused group interview with three students: S1.01, S1.07, and S1.10 (actually, four students, one from each problem-case-4 group, were invited, but only three came, one failed to come at the very last minute).

In addition, at the end of week 10, students were sent an online feedback form. Students evaluated the overall effectiveness of each of the problems cases according to a five-point Likert scales. The comments and suggestions that students did not feel free to give during the problem feedback could be given here.

Reflection. The reflection in this cycle are summarized in 5 outstanding themes.

Theme 1: Students made progress in using level 3 HOTS, employment of level 4 HOTS could not be identified 
As described in Figure 4 and Table 2 , the problem cases increased in HOTS requirements, and the tasks given in each case led students from using thinking skills of lower levels to thinking skills of higher levels as well.

In problem case 1 , it was observed that students appeared quite puzzled having to think (for the very first time for many students) how to apply the domain knowledge and skills in answering a thought-provoking question in problem case 1 . The analysis of students' writings revealed that students' ability to use the skills of categorizing and specifying were not the same: only two students managed to make clear and well-supported arguments of how domain knowledge and skills could be categorized to match the requirements of each task. In the writings of the other students, only simple elaboration could be made with almost no illustration.

In problem case 2, most pairs made detailed comparison between the given letters, and evaluated the choices of words basing on what they had just learnt from the lecture on synonymy and antonymy. On receiving the teacher's questions for clarification (eg. 'Why do you think the style of the letter/ the word is not appropriate?" "Which word is more suitable? Why?" etc.), all the pairs of students provided clarification which varied in terms of how illustration and supporting ideas were used. Task 2 - revising letters - was aimed to encourage students' further use of HOTS and domain knowledge and skills to revise the letters, but I figured out that the revision task did not work effectively with inactive students who just repeated the discussion in class. In some pairs, the revised letters of both students were identical to the other's, and to the version they presented in class, revealing that they made almost no further investment of HOTS in their home revision of letters.

In problem case 3 , task 1 - revision - was conducted at home, but I could still observe through much discussion via email that students did not need too much consultation on how to use HOTS, but mostly about how to deal with the writers' possible opposition to the revisions. The presentations showed that all the five groups of students succeeded in evaluating then revising their peer's word choices: almost all the word substitutions made were appropriate and help enhance the original writing, and their explanation of the need for revision demonstrated that they did use analytical and logical reasoning to prepare meticulous specifying of all the word substitution. Only two groups succeeded in adding figure of speech (metaphor or metonymy) to their peers' writings, which required much abstracting than word substitution in the preparation process. The Q\&A session in task 2 might also be a chance for students to develop their predicting skills and skills of solving real problems (one student voiced up his disagreement to the suggested changes to his writing, so the presenting group had to explain with detailed analysis and meticulous comparison between the original and the changed versions to defend for their revision, before he finally reluctantly accepted those changes). Through the interview, all students said that they were quite confident in their own analysis because they had experience from the 2 previous cases, but in group, evaluating and judging others' suggestion of changes required much time and efforts for negotiating: reasoning, defending, persuading, and then together choosing the best alternative; much persuading and interpersonal skills were used watchfully.

In problem case 4 , the analysis on students' submitted assignments and presentation showed unclear progress in students' use of HOTS: the evaluation and the suggestion for revision were quite simple. In the interview, students all agreed that the case was difficult 
as all the 3 tasks were demanding to them. It took most of the groups almost 5 days to finish task1. In task 2, students managed to make conclusions about the similarities and differences between modality in English and Vietnamese, though most of these were adapted, not their original ideas, but the comments on the equivalence of modality between the original and translated texts were quite general, and suggestions to improve the translation quality were simple. Students explained that their understanding about modality in English and Vietnamese and their translation skills were not enough for them to make well-argued conclusions about the equivalence in terms of modality between the original text and its translated text in terms of modality. Only one group managed to fulfill task 2 quite well, but it was the contribution of one student, not the whole group.

"The conclusion about the similarities and differences in modality (manifestation devices) received good comments, but we didn't take it as our group's success. Credit went to $\mathrm{H}$, who always excelled in learning with her outstanding language proficiency, brilliant creative ideas, acute evaluation, and logical reasoning skills. Though we got higher mark than other groups, we were not so proud of ourselves." (S1.07)

In task 3, although students said they did invest tons of efforts analyzing the texts and discussing on the possible ways to improve the translation quality, not many revision alternatives could be given. Even with the changes they made, they could not give the explanation as detailed and well-supported as what they did in problem case 3. The suggestion of an adapted or newly developed strategy for translating modal devices from English into Vietnamese, as offered by the teacher for a bonus point, was almost neglected.

Theme 2: Learning was meaningful and motivating if the problem cases were practical to students

While observing students in their discussion and presentation, and through the interview, I saw the possible trend that the more practical the problem case was for students' future job, the more motivated the students became. Students seemed very attentive and confident in problem case 1, 2 and 3, which were real situations that they might had tried in their internship. Meanwhile in problem case 4 , they appeared to be less confident and active. It was revealed from the interview that translation was an elective subject for Applied Linguistic students. Only some students chose the translation course and learnt translation skills at a very basic level, while others found those skills unfamiliar, making the problem case rather impractical to them. This might have hindered their contribution to the group assignment.
"We need to learn much more about modality and translation skills to do it well" (S1.01).

Through the online feedback, students' evaluation on the meaningfulness of the problem cases increased from problem case 1 to $3(\mathrm{M}=4.07,4.23,4.38$ respectively), then dropped in problem case $4(\mathrm{M}=4.08)$.

Theme 3: PBL could contribute to change students 'passive learning routines

During problem case 2 in week 4, many pairs of students did have productive discussion about "which letter to be called for the interview": the arguments they gave were no longer a recall of something they heard from the teacher or searched elsewhere, but ideas formed from their original analysis and evaluation of the letters. However, only 2 students were willing to present in class, the other 5 students reluctantly took the role of presenter after negotiation in pair. In problem case 3, I could not observe how students worked in group, but their presentation in class demonstrated good efforts in analyzing 
and evaluating the input writings, which were the evidence of their employment of analytical reasoning skills.

The interview also revealed that the problem cases urged students to work hard, with intense employment of critical thinking skills.

"I spent three nights thinking over and over again about the word substitutions. I checked the dictionaries and thesaurus again and again, [...]. It was time consuming, but I was quite happy about my revision because I understood the detailed shades of meaning of the words." (S1.07)

Such demonstration of active learning was quite different from what I could observe in the previous courses of semantics, in which students were often not active in the discussion activities, just like other Vietnamese students who had long been accustomed to the role of passive acceptors in the lectured-based linguistic classes. (Nguyen et al., 2015)

Students' view on learning had changed after problem case 3 . When I assigned problem case 3, many students immediately raised such questions as: "What would happen if the writing is too good to be revised?" "Might the changes we made ever spoil the original writings?" Observing students' exchange of ideas in class, I could see their hesitation in making revisions to their friends' writing, which was not surprising because disinclination to innovation had always been a typical character of Vietnamese students, and of Vietnamese people in general. In the interview, when all the tasks in problem case 3 had already been fulfilled, I could observe some change in students' view:

"Even already good writings could still be improved." (S1.01).

Theme 4: Too high requirements in professional skills might hinder students' HOTS employment

As mentioned, in the first 3 problem cases, students met (to different degrees) all the requirements in the tasks; while in problem case 4 , only one group managed to fulfill all the 3 tasks. The reason to be figured out through the interview was that: problem case 1 and 2 did not call for students' proficiency in any specific job skills; and problem case 3 required students to revise the writings - the skill that they had been using frequently in their own learning or their part-time job as tutors. Meanwhile, problem case 4 required translation skills, which were not what students had already mastered, at a quite high level. With inadequate experience and limited skills in translation, students were afraid of being criticized for their poor translation, so they spent too much time on task 1 and insufficient time on task 2 and 3. They also said they felt insecure having to give evaluation on others' translations (as their translation might had problems, too); and they were not confident in making revisions and specifying their revision on the use of modal devices "Sometimes it's hard to agree on the best translation" (S1.01). As mentioned, when I asked the students to suggest a strategy for translating modal devices, even to get a bonus point, they showed almost no motivation to do.

Theme 5: Working in groups of people of different styles and levels can be challenging but good practice for problem solving

As described in Table 2, in problem case 3, students worked in groups of their own choices, while in problem case 4 , they worked in groups that the teacher assigned. I was informed from my discussion with students during their group work and from the interview that in problem case 4 , students did struggle a lot more when having to work with people whose learning and thinking styles they were not familiar with. Group members tended to be more critical to others' work, and much more explanation and negotiation had to be made than in problem case 3 "We didn't have much time but too much negotiation to 
be made" (S1.10). Students did not like the negotiation with group members as they had to try to specify their ideas with persuasive arguments, defend their ideas from the critical judgments of other group members. However, solving "real" problems arising when learning and cooperating within the group was practical preparation for students in their future job.

\subsubsection{Cycle 2}

Cycle 2 was conducted in Fall semester of 2016 - 2017 academic year.

Action and Observation. The action in cycle 2 was the revision of the action in cycle 1 as the reflection of cycle 1 informed about some limitations of the intervention.

In cycle 2, the format of problem case 2 was changed into a more ill-structured format, and from a lecture-based decision making to a close-looped (Barrows 1986) trouble-shooting case. The aim of this revision was to increase the thought provocation intensity of the problem case, requiring students to use HOTS at a higher level (as described in Figure 4). In addition, problem case 2 was revised to be conducted in class only (no more home revision of the letters).

In both problem cases 3 and 4, students worked in groups assigned by the teacher. The translation task was cut off from problem case 4 , relocating the focus of the strategic performance more on linguistics and less on translation skills. Also, to prepare students better for problem case 4, I also assigned students with readings on modality in Vietnamese so that they could have a source of reference to generalize the similarities and differences of modal devices in English and Vietnamese.

The biggest revision made in cycle 2 was in the description of the problem cases and the teacher's instruction on how to proceed during their problem solving process. In cycle 1, I gave detailed instructions on which steps to take to solve the problems in the form of explicit tasks. In cycle 2, however, such detailed instructions were only given in the very first problem case. In the other 3 cases, although the detailed instructions with prescriptive tasks had been already planned by the teacher, the plan was changed right after week 2 due to a special situation observed in problem case 1 (further elaborated in Reflection). In the last 3 problem cases, students (in pairs or groups) were supposed to decide their own way to address the problems, the teacher only facilitated when students really needed clarification of the concepts, ideals, or consultation about group work skills. Instructions on how the problems should be addressed were minimized so that students were free to discuss and decide their own approach in addressing the problems.

Students' performance in response to the problem cases (writing, editing assignments, and presentations) was analyzed using the HOTS analyzing scheme (Appendix 1) to seek for the evidence of how they actually employed HOTS. Students' contribution to pair or group discussion, their motivation, their comments about the problem difficulty or their expectation for revision of the cases were also observed in the lesson and through consultation emails.

Right after the problem cases, the teacher elicited students' comments on their procedure of solving the problems through informal discussion. A semi-structured focused group interview was conducted with 4 leaders of the groups (coded as S2.4, S2.6, S2.10, S2.14).

Reflection. The reflection in this cycle are summarized in 4 outstanding themes.

Theme 1: Students made progress in their ability to use HOTS

Students' progress in their ability to use HOTS throughout the problem cases in this cycle could be summarized in Table 3 . 
Table 3. Students progress in using HOTS

\begin{tabular}{|c|c|c|c|c|c|}
\hline HoIs employed & Problem case 1 & Problem case? & Problem case 3 & Problem case 4 & HOIs utilization \\
\hline $\begin{array}{l}\text { CATEGORIZING } \\
\text { (la) }\end{array}$ & 2.4 & & & & $\begin{array}{l}\text { Good (Mean }=2.6-3.0) \\
\text { Fair (Mean }=1.8-2.5) \\
\text { Poor (Mean }=1.0-1.7)\end{array}$ \\
\hline \multirow{2}{*}{$\begin{array}{l}\text { SPECIFYING } \\
(2 c, 3 c, 4 c)\end{array}$} & & & 2.75 & & Good (Mean $=2.6-3.0)$ \\
\hline & 2.07 & 2.13 & & 2.5 & $\begin{array}{l}\text { Fair (Mean }=1.8-2.5) \\
\text { Poor (Mean }=1.0 .1 .7)\end{array}$ \\
\hline \multirow[b]{2}{*}{$\begin{array}{c}\text { EVALUATING } \\
(2 \mathrm{a}, 3 \mathrm{a}, 4 \mathrm{a})\end{array}$} & & & 2.75 & 2.75 & Good (Mean $=2.6-3.0)$ \\
\hline & & 2.67 & & & $\begin{array}{l}\text { Fair (Mean }=1.8-2.5) \\
\text { Poor (Mean }=1.0-1.7)\end{array}$ \\
\hline \multirow{2}{*}{$\begin{array}{l}\text { REVISING } \\
(2 \mathrm{~b}, 3 \mathrm{~b}, 4 \mathrm{~d})\end{array}$} & & & 2.75 & & Good (Mean $=2.6-3.0)$ \\
\hline & & 2.13 & & 2.5 & $\begin{array}{l}\text { Fair (Mean }=1.8-2.5) \\
\text { Poor (Mean }=1.0 .1 .77\end{array}$ \\
\hline \multirow{3}{*}{$\begin{array}{c}\text { DEFENDING } \\
(3 \mathrm{~d}, 4 \mathrm{e})\end{array}$} & & & & & Good (Mean $=2.6-3.0)$ \\
\hline & & & 2.5 & 2.5 & Fair (Mean $=1.8-2.5)$ \\
\hline & & & & & Poor (Mean $=1.0-1.7)$ \\
\hline \multirow{3}{*}{$\underset{(4 \mathrm{~b})}{\text { GENERLIZING }}$} & & & & & Good (Mean $=2.6-3.0)$ \\
\hline & & & & 2.5 & Fair (Mean $=1.8-2.5)$ \\
\hline & & & & & Poor (Mean $=1.0 \cdot 1.7)$ \\
\hline ADAPTING & & & & & Good (Meanl $=2.6-3.0)$ \\
\hline $\begin{array}{l}\text { EXISTINGSTRATEGY } \\
\text { (4fl) }\end{array}$ & & & & 2 & $\begin{array}{l}\text { Fair (Mean }=1.8-2.5) \\
\text { Poor (Mean }=1.0-1.7)\end{array}$ \\
\hline \multirow{4}{*}{$\begin{array}{c}\text { DEVELLPPNG NEW } \\
\text { STRATEGY } \\
(4 \mathrm{f} 2)\end{array}$} & & & & & Good (Mean $=2.6-3.0)$ \\
\hline & & & & 2 & Fair (Mean $=1.8-2.5)$ \\
\hline & & & & & Poor (Mean = 1.0-1.7) \\
\hline & \multicolumn{2}{|c|}{$\mathrm{N}=15$ (students) } & \multicolumn{2}{|c|}{$\mathrm{N}=4$ (groups) } & \\
\hline
\end{tabular}

As demonstrated in Table 3, students made progress the most in their specifying, evaluating, and revising skills; and the thinking skills to be enhanced the most was evaluating. In problem case 4 , students' revision on the use of modal devices in the translated version was not as detailed as what they did in revising the writing in problem case 3 . Their ability to specify for the revising options was not as good as what they performed in problem case 3 , either. The interview revealed that students' revision on the translation of the modal devices was very much constrained by their understanding about Vietnamese modal devices. Students believed they need more explanation from the teacher to understand the readings thoroughly, so that they were better informed and assisted in their revision of modal devices and specification for their revision.

Table 3 also showed that the students could use level 4 HOTS such as adapting or developing the translation strategy when they were asked to, but their employment of these skills was limited as this was the first time they were required to use such skills in their learning. Also, as mentioned, their understanding about modal devices and translation skills were still limited for such a demanding job to be fulfilled. 
Theme 2: Too much detailed instruction might hinder students' creativity in problem solving

As mentioned, in this cycle, I initially planned to give students a list of tasks to be fulfilled in each problem case with the assumption that the prescribed tasks could be of good assistance for students in their employment of HOTS, for HOTS requirements were made explicit in the task description. However, in problem case 1, while most students start the discussion without hesitations, one student raised questions about the tasking procedure.

"Do I have to discuss in pair? Or could

I discuss in group? Or think by myself?

Do I need to write exactly from 200 to

300 words? Could I write in fewer or more words?" (S2.10)

I then observed that she did not discussed with the student who was sitting next to her (I supposed they could pair up), but teamed up with other 2 students for the discussion. The analysis of her writing then revealed that she was very creative in her thinking, and her writing were very logically structured and well argued, demonstrating her perfect logical thinking and specifying skills. I then figured out that too detailed instruction on how to address the problem did not always help students, but might even hinder their creativity in problem solving. I therefore decided to stop prescribing the tasks in the forthcoming problem cases. Instead, I encouraged students to seek for further instruction as much as they needed, and I realized that such a way of coaching students made them feel free to decide the way to address the problem, which encouraged their creativity, and might have positive influence on promoting their autonomy in learning.

Theme 3: HOTS were employed more effectively when problems were solved in groups
As demonstrated in Table 3, there was a significant development in students' ability of specifying, evaluating, and revising when they worked in groups. It was then clarified in the interview that before the assignments were presented in class, students had to use HOTS much in all the preparation activities they did in group. The group work process in problem case 3 and 4 was described as a mixture of explaining, questioning, specifying, evaluating, and defending. The group assignments went through a lot of discussion and revisions before they were finalized and presented in class. Problems emerged during group work, and then solved. Group work was therefore much more demanding to students. Before students present in class, it seemed students had the so-called "rehearsal" for their presentation, in which one's ideas must be elaborated to persuade other members, limitations were found through critical evaluation, and then fixed with careful revision.

"I was assigned into a group of 4 , all were of different working styles, all were very critical. So, usually, I needed strong and persuasive arguments for my ideas to be accepted by other members. It's like defending my ideas against others' judgment. People think differently, so it took time to discuss, modify, and agree on the final decision". (S2.14)

All the group preparation prior to class presentation functioned as a good chance for students to practice problem solving skills and the HOTS required for problem solving.

Theme 4: The use of the closed-loop problem case stimulated and drove students' learning

Problem case 2 in this cycle had been changed from a lecture-based problem case into a closed-loop problem case, and its design was also changed from a decision-making case to a trouble shooting case. Apart from increasing the degree of ill-structuredness 
and thought provocation, the reason for such modification was that: the contents of week 4 lecture (sense relations: synonymy and antonymy) were neither too abstract nor too complex for students' self-direct learning. Without too specific linguistic background knowledge and without teacher's lecturing, students could still solve the assigned problem at the basic requirements in pair.

As the problem case was raised prior to students' learning of synonymy and antonymy, students, at first, could not do the revision task well. They made a lot of comments to the letters, pointing out the limitations that might be the reason why the letters were rejected, but they could not revise all those limitations. Also, the revisions were not well specified by all the pairs.

"We just felt in many parts that the wordings of the letters were inappropriate, because you said the writers were interviewed. But we were not sure whether our revision made the letters better" (S2.04).

I could observe many students' uncertainty about whether their revised versions were a good improvement. Many questions were raised: "Do we need to change the words? Can I rewrite the whole paragraph my way?", "How many changes are enough?". However, such uncertainty was a kind of stimulus for students to learn, and it was the driving force for students' learning when they then read Chapter 2 about the types of synonyms and antonyms. I could observe students automatically paired up to check their revisions right after reading the materials about synonymy and antonymy. They discussed actively while reading; and four pairs did modify their already-revised letters.

"Reading Chapter 2 did not take long, but our discussion took much longer. We read and found what we need for the revision tasks, so we then looked back at the letters. The types of synonyms and antonyms could help in the revision." (S02.14)
After reading the materials, not many revisions were modified, but the students were then able to explain the how each revision influenced the wording, and the impression that the letters might make on the readers. I could also observe that students' material reading, discussion and pair work became very active after problem case 2 was raised, much more active than what students did in the same class session in cycle 1 (when problem case 2 was lectured-based). Problem case 2 in this cycle functioned as the means to provoke students' thinking, opening their curiosity loop; and all the reading, discussion, and modification afterwards were to close this loop. Learning became goal oriented; the learning goal was to solve, then improved the solution to the problem raised.

\section{Conclusions and recommendation}

The research findings lead to some conclusions. First, PBL was proved to be an appropriate approach to promote Vietnamese students' use of HOTS in linguistic courses. The problem-based learning activities could, therefore, be designed to efficiently facilitate students' learning of linguistics or other content subjects in contexts similar to Vietnamese tertiary education context (where the teaching and learning of content subjects are still teachercentered and HOTS are not yet an integral part of the curriculum). Also, PBL contributed to change Vietnamese students' passive learning routines into more active and responsible learning. This conclusion resonates Bell's (2012) position that PBL help students become independent learners and take responsibility for their learning, laying the ground for developing their metacoginitive skills and lifelong learning skills. Second, when students were given more control to self-direct and self-regulate their learning, they could actively draw on their creativity more efficiently in learning. Therefore, the teacher in the PBL class should make careful consideration about the degree of teacher facilitation needed in 
the class. Third, when the linguistics contents did not necessitate teacher's lecturing on specific abstract or complex linguistic issues, the closed-loop problem case could be more efficient than the lecture-based case in the sense that it could stimulate students' need to learn and drive students' goal-oriented learning. Fourth, students appeared more motivated in problem cases which were of their interest or which they might have experience with during their internship and part-time jobs (problem case 2 and problem case 3 ). This echos Hung \& Holen's (2011) remark about the affective factors of problem cases. Also, when PBL was conducted in groups of different learning styles and levels, students were challenged more, but had more chance to practice their problem solving skills. They also had chance to practice and improve their persuading, presenting, negotiating, group work skills.

The limitation of this study is in the inadequate focus on level 4 HOTS. The problem cases in both cycles were designed to require students for much exploitation of level 3 HOTS in learning, but not much employment of level 4 HOTS. Evidence of students' progress in using level 4 HOTS was therefore not clearly identified. In the next cycle, the number of problem cases might be added, and the requirement on the use of level 4 HOTS might be extended so that students' thinking skills could be developed all-sidedly.

\section{References}

Barrett, T., Moore, S. (2011). New approaches to problem-based learning: revitalizing your practice in higher education. New York: Routledge.

Barows, H.S. \& Tamblyn, R.M. (1980). Problem-based learning. New York: Springer.

Barrows, H.S. (1986). A taxonomy of problem-based learning methods. Medical Education, 20, 481-486.

Barrows, H.S. (1994). Practice-based learning: Problem-based learning applied to medicine education. Springfield, IL: Southern Illinois University School of Medicine.

Bell, J. (2012). Introducing problem-based learning as a learning strategy for master students. Practitioner Research in Higher Education, 6(1), 3-11.
Bransford.J.D\& Stein, B.S. (1984). The IDEAL problem solver. New York: W.H. Freeman.

Brookhart, S. M. (2010). How to assess higher-order thinking skills in your classroom. Alexandria, VA: ASCD.

Burn, A. (2010). Doing action research in English language teaching: A guide for practitioners. NewYork: Routledge.

Caswell, C.A. (2016). Design and Facilitation of problem-based learning in graduate teacher education: An MA TESOL case. Interdisciplinary Journal of Problem-based Learning, 11(1). Available at: https://dx.doi.org/10.7771/1541-5015.1623

Chinedu, C.C. Kamin, Y, \& Olabiyi, O.S. (2015) Strategies for improving higher-order thinking skills in teaching and learning of design and technological education. Journal of Technical Education and Training, 7(2), 35-43.

Colliver, J.A. (2000). Effectiveness of problem-based learning curricula: Research and Theory. Academic Medicine 75(3), 259-266.

deChambeau, A., Ramlo, S.E. (2017). STEM high school teachers' views of implementing PBL: An investigation using anecdote circles. Interdisciplinary Journal of Problem-based Learning, 11(1). Available at: https://dx.doi. org/10.7771/1541-5015.1566

Dolmans, D.H.J.M et al. (2005) Problem-based learning: future challenges for educational practice and research. Medicine Education 39, 732-741

Forrester, V. \& Chau, J. (1999). Current developments in problem based learning within the Hong Kong Institute of Education. In J. Marsh (Ed.) Implementing Problem Based Learning Project: Proceedings of the First Asia Pacific Conference on Problem Based Learning (pp.201-208). Hong Kong: The University Grants Committee of Hong Kong, Teaching Development Project. Retrieved from http://teaching.polyu.edu.hk/datafiles/R100.pdf

Hendry, G., Wiggins, S., \& Anderson, T. (2016). Are you still with us? Managing mobile phone use and group interaction in PBL. Interdisciplinary Journal of Problem-based Learning, 10(2). Available at: http:// dx.doi.org/10.7771/1541-5015.1600

Heong, M.Y., Yunos, J.B.M., Hassan, R.B., Othman, W.B., \& Kiong, T.T. (2011). The perception of the level of higher order thinking skills among technical educational students. 2011 International Conference on Social Science and Humanity IPEDR Vol.5 (V2pp.281-285). Singapore: IACSIT Press.

Hmelo-Silver, C.E. \& Barrows, H.S. (2006). Goals and strategies of a problem-based learning facilitator. Interdisciplinary Journal of Problembased Learning, 1(1). Available at: http://dx.doi. org/10.7771/1541-5015.1004

Hmelo-Silver, C.E. \& Simone, D.C (2013). Problembased learning: An instructional model of collaborative learning. In C.E.Hmelo-Silver, A.M.O'Donnell, C.K.K.Chan \& C.Chin (Eds) 
International Handbooks of collaborative learning. New York: Taylor and Francis.

Hmelo-Silver, C.E. (2004). Problem-based learning: What and how do students learn? Educational Psychology Review, 16, 235-266.

Hmelo-Silver, C.E, Derry, S.J., Bitterman, A, Hatrak, N. (2009). Targeting transfer in STELLAR PBL course for pre-service teachers. Interdisciplinary Journal of Problem-based Learning, 3, 24-42.

Hung, W. (2009). The 9-step problem design process for problem-based learning: Application of the 3C3R model. Educational Research Review, 4(2009), 118-141.

Hung, W., \& Holen, J. B. (2011) Problem-based learning: Preparing pre-service teachers for real world classroom challenges. ERS Spectrum, 2(3), 29-48.

Hung, W., Mehl, K., \& Holen, J. B. (2013). The relationships between problem design and learning process in problem-based learning environments: Two cases. The Asia-Pacific Education Researcher, 22(4), 635-645. Available at: http://dx.doi. org/10.1007/s40299-013-0066-0

Hung, W., Jonassen, D. H., \& Liu, R. (2008). Problem-based learning. In J. M. Spector, J. G. van Merrienboer, M. D., Merrill, \& M. Driscoll (Eds.), Handbook of research on educational communications and technology (3rd ed.), 485-506. New York, NY: Erlbaum.

Hung, W. (2016). All PBL starts here: The problem. Interdisciplinary Journal of Problem-based Learning, 10(2). Available at: http://dx.doi. org/10.7771/1541-5015.1604

Jonassen, D.H \& Hung, W. (2008). All problems are not equal: Implications for PBL. Interdisciplinary Journal of Problem Based Learning, 2(2), 6-28.

King, F., Goodson, L., \& Rohani, F. (2011). Higher order thinking skills: Definitions, strategies, assessment. Center for Advancement of Learning and Assessment. Tallahassee, FL: Florida State University.

Knowles, M. (1984). Andragogy in Action. San Francisco: Jossey-Bass.

Lambe, J. (2007). Student teachers, special education needs and inclusion education: Reviewing the potential for problem-based, e-learning pedagogy to support practice. Journal of Education for Teaching: International Research Pedagogy, 33, 359-377.

Magi, S. (2003). Facilitating Problem-Based Learning: Illuminating Perspectives. Philadelphia: The Society for Research in Higher Education and Open University Press.

Marzano, R.J. \& Kendall, J.S. (2007). The new taxonomy of educational objectives (2nd ed.) Thousand Oaks, CA: Corwin Press.

Nguyen, T. M. T., Nguyen, H. D., Nguyen, L. T. T., Doan, N. T. (2015). Students' employment of high-order thinking skills in English Linguistics Courses assessment: A case study at VNU-ULIS, Proceedings of An ELT Conference on Innovative
English Language Teaching for Provincial Universities, 215-220. Quảng Bình: Quảng Bình University Press.

Nguyen, T. M. T \& Nguyen, L. T. T. (2016). Integrating higher-order thinking skills (HOTS) development with teaching English linguistics: An action research conducted at VNU-University of Languages and International Studies (VNU-ULIS). Proceedings of the International Conference on Reseach on Innovations in Language Teaching, 220-230. Huế: Huế University Press.

Pourshafie, T. \& Murray-Harvey, R. (2013). Facilitating problem-based learning in teacher education: getting the challenge right. Journal of Education for Teaching: International Research and Pedagogy, 39(2). Available at: http://dx.doi.org/10.1080/0260 7476.2013.765190

Rajendran, N. \& Idris, P.U.P.S. (2008). Teaching and Acquiring Higher Order thinking skills: Theory and Practice. Penerbit University Pendidikan Sultan Idris.

Ribeiro, L.C. (2011). The Pros and Cons of Problembased learning from the teacher's standpoint. Journal of University Teaching and Learning Practice, 8(1), 1-17.

Schetino, C. (2016). A framework for problem-based learning: Teaching mathematics with a relational problem-based pedagogy. Interdisciplinary Journal of Problem-based Learning 10(2). Available at: http://dx.doi.org/10.7771/1541-5015.1602

Scholkmann and Roters (2009). Measuring the effects of problem-based learning (PBL). Paper presented at ECER 2009 Sept $28^{\text {th }}-30^{\text {th }}$ Vienna.

Simone, C.D (2014) Problem-based learning in teacher education: Trajectories of change. International Journal of Humanities and Social Sciences, 4(12), 17-29.

Sipes, S.M. (2016). Development of a problem-based learning matrix for data collection. Interdisciplinary Journal of Problem-based Learning, 11(1). Available at: https://dx.doi.org/10.7771/1541-5015.1615

vanBerkel, H.J \& Schmidt, H.G. (2000). Motivation to commit oneself as a determinant of achievement in problem-based learning. Higher Education, 40, 231242.

Walker, A.E. \& Leary, H. (2009). A problem-based learning meta-analysis: Differences across problem types, implementation types, disciplines, and assessment levels. Interdisciplinary Journal of Problem-based Learning, 3, 12-43. Available at: https://dx.doi.org/10.7771/1541-5015.1061

Wilkerson, L. \& Gijselaers, W. H. (Eds) (1996). Bringing problem-based learning to higher education: Theory and practice. San Francisco: Jossey-Bass.

Zhang, M. Ludeberg, M., McConnell, T. Koehler, M., Eberhardt, J. (2010). Using questioning to facilitate discussion of science teaching problems in teacher professional development. Interdisciplinary Journal of Problem-based Learning, 4, 57-82. Available at: http://dx.doi.org/10.7771/1541-5015.1097 


\title{
ÁP DỤNG ĐƯờNG HƯớNG DẠY HỌC GIẢI QUYÊTT VẤN ĐỀ ĐỂ THÚC ĐẨY VIỆC SỬ DỤNG KỸ NĂNG TỦ DUY BậC CAO TRONG QUÁ TRİNH HỌC TậP CỦA SINH VIÊN
}

\author{
Nguyễn Thị Minh Tâm \\ Khoa Ngôn ngũ và Văn hóa các nước nói tiếng Anh, Trưòng Đại học Ngoại ngũu, ĐHQGHN, \\ Phạm Văn Đồng, Cầu Giấy, Hà Nội, Việt Nam
}

Tóm tắt: Bài báo mô tả một nghiên cứu cải tiến sư phạm trong học phần Ngữ nghĩa học dành cho sinh viên năm cuối của một trường đại học ở Việt Nam. Với giả thuyết rằng đường hướng dạy học giải quyết vấn (problem-based learning - PBL) có thể khuyến khích người học sử dụng kỹ năng tư duy bậc cao và hỗ trợ họ trong quá trình học, tác giả đã thiết kế các hoạt động học xoay quanh việc sinh viên phải sử dụng tư duy bậc cao (higher-order thinking skills - HOTS) để giải quyết các vấn đề được nêu hoặc được yêu cầu khám phá và tìm cách giải quyết qua hoạt động học. Vào thời điểm bài báo được viết, nghiên cứu sư phạm đã hoàn thành hai chu kỳ nghiên cứu, mỗi chu kỳ kéo dài 9 tuần. Các khách thể của nghiên cứu là 31 sinh viên theo học Ngôn ngữ học ứng dụng tại một trường đại học chuyên ngữ ở Việt Nam. Kết quả của nghiên cứu được thảo luận để làm rõ mức độ tác động của đường hướng dạy học giải quyết vấn đề PBL lên khả năng sử dụng kỹ năng tư duy bậc cao của các sinh viên tham gia trong nghiên cứu và khả năng đường hướng này có thể hỗ trợ quá trình học tập của sinh viên trong học phần Ngữ nghĩa học.

Tù khóa: kỹ năng tư duy bậc cao, dạy học giải quyết vấn đề (PBL), ngữ nghĩa học 


\section{APPENDIX 1: CYCLE 2 HOTS ANALYZING SCHEME} (USED IN PRESENTATION AND ASSIGNMENT ANALYSIS)

(1) no evidence of use (2) unclear evidence of use (3) clear evidence of use

\begin{tabular}{|c|c|c|c|}
\hline Problem cases & Evidence of HOTS employment & Level & Notes \\
\hline \multirow{6}{*}{$\begin{array}{l}\text { 1. How to use the } \\
\text { linguistic knowledge and } \\
\text { skills you've learnt in } \\
\text { your future job? }\end{array}$} & \multirow{3}{*}{$\begin{array}{l}\text { a. Categorize the aspects of knowledge and skills } \\
\text { according to different tasks in the future jobs. }\end{array}$} & (3) & \\
\hline & & (2) & \\
\hline & & (1) & \\
\hline & \multirow{3}{*}{$\begin{array}{l}\text { b. Specify how those aspects of knowledge and } \\
\text { skills would help students to fulfill those tasks. }\end{array}$} & (3) & \\
\hline & & (2) & \\
\hline & & (1) & \\
\hline \multirow{9}{*}{$\begin{array}{l}\text { 2. The given application } \\
\text { letters were not good } \\
\text { enough so the applicants } \\
\text { were not called for } \\
\text { interviewed. What } \\
\text { changes to be made and } \\
\text { why? }\end{array}$} & \multirow{3}{*}{$\begin{array}{l}\text { a. Evaluate and point out the problems in the two } \\
\text { letters with explanation. }\end{array}$} & (3) & \\
\hline & & (2) & \\
\hline & & (1) & \\
\hline & \multirow{3}{*}{ b. Suggest ways to revise the problems found. } & (3) & \\
\hline & & (2) & \\
\hline & & (1) & \\
\hline & \multirow{3}{*}{$\begin{array}{l}\text { c. Specify why each revision is necessary (students } \\
\text { give specification with or without the teacher's } \\
\text { guiding questions). }\end{array}$} & (3) & \\
\hline & & (2) & \\
\hline & & (1) & \\
\hline \multirow{12}{*}{$\begin{array}{l}\text { 3. The given writings are } \\
\text { not yet good enough to be } \\
\text { used as sample writings } \\
\text { for students or other } \\
\text { writers. Make changes in } \\
\text { terms of lexical choices } \\
\text { and figure of speech } \\
\text { to make them the ideal } \\
\text { sample writing. }\end{array}$} & \multirow{3}{*}{ a. Evaluate the wording and style of the writing. } & (3) & \\
\hline & & (2) & \\
\hline & & (1) & \\
\hline & \multirow{3}{*}{ b. Make changes to revise the writing } & (3) & \\
\hline & & (2) & \\
\hline & & (1) & \\
\hline & \multirow{3}{*}{ c. Specify the changes made to the writing. } & (3) & \\
\hline & & (2) & \\
\hline & & (1) & \\
\hline & \multirow{3}{*}{$\begin{array}{l}\text { d. Defend their revision when the writer raised } \\
\text { opposition to it. }\end{array}$} & (3) & \\
\hline & & (2) & \\
\hline & & (1) & \\
\hline \multirow{20}{*}{$\begin{array}{l}\text { 4. The translated versions } \\
\text { are not yet the most } \\
\text { equivalent enough to } \\
\text { the original version in } \\
\text { English, especially in } \\
\text { terms of modality. Make } \\
\text { changes to the translation. } \\
\text { Suggest the best strategy } \\
\text { to translate modality } \\
\text { manifestation devices. }\end{array}$} & \multirow{3}{*}{ a. Evaluate the translated version; } & (3) & \\
\hline & & (2) & \\
\hline & & (1) & \\
\hline & \multirow{3}{*}{$\begin{array}{l}\text { b. Generalize to point out the similarities and } \\
\text { differences in modality in English and Vietnamese. }\end{array}$} & (3) & \\
\hline & & (2) & \\
\hline & & (1) & \\
\hline & \multirow{2}{*}{ c. Revise the modal devices in the translation } & (3) & \\
\hline & & (2) & \\
\hline & \multirow{3}{*}{ d. Specify the changes made to the modal devices } & (3) & \\
\hline & & (2) & \\
\hline & & (1) & \\
\hline & \multirow{3}{*}{$\begin{array}{l}\text { e. Defend their revision when audience raised } \\
\text { opposition to it. }\end{array}$} & (3) & \\
\hline & & (2) & \\
\hline & & (1) & \\
\hline & \multirow{3}{*}{$\begin{array}{l}\text { f1. Develop an adapted strategy (suggestions) } \\
\text { to translate modality manifestation devices from } \\
\text { English into Vietnamese. }\end{array}$} & (3) & \\
\hline & & (2) & \\
\hline & & (1) & \\
\hline & \multirow{3}{*}{$\begin{array}{l}\text { f2. Develop an original strategy (suggestions) } \\
\text { to translate modality manifestation devices from } \\
\text { English into Vietnamese. }\end{array}$} & (3) & \\
\hline & & (2) & \\
\hline & & (1) & \\
\hline
\end{tabular}

